\title{
Pelepasan Eretmocerus sp. (Hymenoptera: Aphelinidae) untuk Mengendalikan Bemisia tabaci Gennadius (Homoptera: Aleyrodidae) pada Tanaman Tomat Hidroponik
}

\author{
Sudarjat $^{1^{*}}$, Yadi Supriyadi ${ }^{1}$ dan Ramdhani ${ }^{2}$ \\ ${ }^{1}$ Departemen Hama dan Penyakit Tumbuhan, Fakultas Pertanian, Universitas Padjadjaran \\ Kampus Jatinangor, Jatinangor 45363 \\ ${ }^{2}$ Departemen Hama dan Penyakit Tumbuhan, Fakultas Pertanian, Universitas Padjadjaran \\ *Alamat korespondensi: sudarjat@unpad.ac.id
}

\begin{abstract}
The Augmentation of Parasitic Wasp Eretmocerus sp. (Hymenoptera: Aphelinidae) to Control Bemisia tabaci Gennadius (Homoptera: Aleyrodidae) in Hidroponic Tomatoes
\end{abstract}

Sweet potato whitefly Bemisia tabaci Gennadius (Homoptera: Aleyrodidae) is one of the most important agricultural insect pests especially vegetables in Indonesia. One of techniques to control this pest is the used of parasitic wasp Eretmocerus sp. This research aimed to find out an effective dose and interval application of Eretmocerus sp. release against B. tabaci at hydroponic tomatoes. This research was carried at the green house, Department of Plant Pests and Diseases, Faculty of Agriculture, Universitas Padjadjaran. The experiment was arranged in a Randomized Block Design consisting of nine treatments and three replications. The treatments were the combination between doses (2, 4 and 8 pupae of Eretmocerus sp.) and interval applications (1, 2 and 3 weeks). The result showed that doses of Eretmocerus sp. released and interval application had effect on parasitization level in the fifth and sixth week after first release. The highest parasitization occurred at treatment of releasing 8 pupae at one week interval (24.63\%). However, the parasitization level at first week until fifth week had no significant different among treatments. The low level of parasitization may be caused by high population of $B$. tabaci at the first release, high temperature in greenhouse, different host plant of Eretmocerus sp. between mass rearing and treatment, not enough number of the released Eretmocerus sp., and the attack of Oidium sp., the patogen of powdery mildew disease on tomato.

Keywords: Augmentation, Eretmocerus sp., Hydroponic tomatoes, Bemisia tabaci

\begin{abstract}
ABSTRAK
Bemisia tabaci Gennadius (Homoptera; Aleyrodidae) atau lebih dikenal kutu kebul, merupakan salah satu hama penting yang menyerang beberapa komoditas pertanian khususnya sayuran di Indonesia. Salah satu teknik pengendalian yang ramah lingkungan yaitu dengan menggunakan parasitoid nimfa Eretmocerus sp. Penelitian ini bertujuan untuk mengetahui dosis dan interval aplikasi pelepasan Eretmocerus sp. sehingga efektif dalam menekan populasi B. tabaci pada tanaman tomat hidroponik. Penelitian dilaksanakan di rumah kaca Jurusan Hama dan Penyakit Tumbuhan Fakultas Pertanian, Universitas Padjadjaran, Jatinangor. Metode yang digunakan adalah metode eksperimen dengan Rancangan Acak Kelompok (RAK). Terdapat sembilan perlakuan dan tiga ulangan yang merupakan kombinasi perlakuan antara dosis (jumlah pupa yang dilepaskan) yaitu 2, 4, dan 8 pupa Eretmocerus sp. dengan interval aplikasi yaitu 1 minggu, 2 minggu dan 3 minggu sekali. Hasil Penelitian menunjukkan dosis dan interval aplikasi mempengaruhi tingkat parasitisasi pada minggu kelima dan minggu keenam setelah pelepasan pertama dengan tingkat parasitisasi tertinggi mencapai 24,63\% pada pelepasan 8 pupa dengan interval 1 minggu sekali. Akan tetapi, tingkat parasitisasi pada minggu pertama sampai minggu kelima masih sangat rendah pada seluruh perlakuan berkisar antara 2,49\%-11,42\% atau seluruh perlakuan tidak berbeda nyata. Rendahnya
\end{abstract}


tingkat parasitisasi Eretmocerus sp. pada penelitian ini disebabkan oleh tingginya populasi $B$. tabaci pada perlakuan pertama, tingginya temperatur di dalam rumah kaca, perbedaan tanaman inang ketika perbanyakan dan percobaan, kurangnya jumlah Eretmocerus sp. yang dilepaskan, dan serangan jamur Oidium sp. penyebab penyakit embun tepung.

Kata Kunci: Pelepasan, Eretmocerus sp., tomat hidroponik, Bemisia tabaci

\section{PENDAHULUAN}

Kutu kebul atau Bemisia tabaci merupakan hama penting yang dapat menyerang berbagai komoditas pertanian termasuk pada tomat hidroponik. Karakteristik B. tabaci adalah polifag, mempunyai tingkat migrasi yang tinggi, tingkat reproduksi yang tinggi (Naranjo \& Ellsworth, 2003), dapat hidup pada dataran tinggi dan dataran rendah (Wiyono, 2007), dan mampu hidup pada kisaran suhu $17-30^{\circ} \mathrm{C}$ (Bonaro et al., 2007) sehingga ini mempunyai sebaran yang luas dan terdapat di seluruh dunia (Gerling \& Mayer, 1996).

Cara pengendalian yang dapat dilakukan untuk mengendalikan $B$. tabaci sesuai dengan prinsif Pengandalian Hama Terpadu (PHT) adalah kultur teknis, pengendalian mekanis, tanaman inang yang tahan, pestisida, serta pengendalian hayati (Hilje et al., 2001 dalam Ardeh, 2004). Di Indonesia, penggunan pestisida merupakan cara pengendalian yang sering dilakukan. Selain keberadaan $B$. tabaci yang berada di bawah daun sehingga sulit terjangkau insektisida (Ardeh, 2004), penggunaan insektisida yang berlebihan juga dapat menimbulkan dampak negatif seperti timbulnya resistensi, residu pestisida pada hasil panen, serta dapat membunuh organisme bukan sasaran termasuk musuh alami seperti predator dan parasitoid (Untung, 2001).

Dengan adanya berbagai dampak negatif dari insektisida, pada saat ini pengendalian $B$. tabaci lebih diarahkan pada pemanfaatan agens pengendali hayati yang lebih ramah lingkungan (Gerling et al., 2001). Parasitoid merupakan salah satu agens pengendali hayati yang beraksi dengan cara memarasit serangga lain (Oka, 2005). Parasitoid yang berpotensi untuk mengendalikan B. tabaci adalah spesies Eretmocerus sp. dan Encarsia sp. (Ardeh, 2004; Zolnerowich \& Rose, 2008; Selina \& Bledsoe, 2002). Kedua parasitoid ini mempunyai potensi yang tinggi sebagai agens pengendali hayati $B$. tabaci. Pengendalian Trialeurodes vaporariorum dengan mengunakan Eretmocerus sp. di rumah kaca telah berhasil dilakukan di Inggris, Australia, Selandia baru dan Kanada (van lenteren dan Woets, 1998 dalam Ardeh, 2004). Tingkat parasitisasi spesies
Eretmocerus terhadap nimfa B. tabaci pada tanaman Gossypium hirsutum (kapas) di Afrika Barat mencapai 88,7\% (Otoidobiga, 2003) dan pada tanaman Convolvulus arvensis (bunga sepatu) 38$69 \%$ (Naveed et al., 2003). Tingkat parasitasi parastoid dipengaruhi oleh jenis tanaman inang (Suarez et al., 2003), bentuk dan panjang trichoma, lebar daun tanaman inang (Ardeh, 2004), dan kepadatan populasi inang (Untung, 2001).

$\mathrm{Di}$ Amerika serikat dan Australia perkembangan agens pengendali hayati khususnya parasitoid telah berlangsung dengan cepat. Terbukti pada saat ini telah diperjualbelikan produk parasitoid Eretmocerus sp. untuk mengendalikan $T$. vaporarioum di rumah kaca dalam berbagai bentuk seperti dalam kertas pias dan botol (Biobest, 2008; Syngenta Bioline, 2008). Untuk pengendalian $B$. tabaci pada pointsetia di rumah kaca telah dilakukan pelepasan parasitoid Eretmocerus dengan dosis 4-8 imago per tanaman per minggu pada kepadatan $B$. tabaci 4-7 nimfa per daun. Hasilnya, perlakuan ini mampu menekan jumlah nimfa $B$. tabaci sebesar 98\% dengan asumsi kemunculan 70\% (van Driesche \& Lyon, 2003).

Dari uraian di atas dapat dilihat bahwa penggunaan parasitoid Eretmocerus sp. mempunyai potensi yang baik untuk dikembangkan sebagai salah satu teknik pengendalian B. tabaci. Untuk itu, diperlukan penelitian untuk mengetahui dosis dan interval dalam pelepasan Eretmocerus sp. untuk mengandalikan B. tabaci pada tanaman tomat hidroponik di rumah kaca.

\section{BAHAN DAN METODE}

Penelitian dilakukan di Rumah Kaca Departemen Hama dan Penyakit Tumbuhan Fakultas Pertanian Universitas Padjadjaran, Jatinangor pada ketinggian tempat \pm 700 mdpl. Parasitoid Eretmocerus sp. yang digunakan dalam penelitian ini didapat dari hasil eksplorasi di beberapa sentra sayuran yaitu Desa Lebak Muncang dan Desa Panundaan Kecamatan Ciwidey Kabupaten Bandung (1300 mdpl), Desa Citarik Kecamatan Titramulya Kabupaten Karawang (15-25 mdpl), dan 
kecamatan Sliyeg Kabupaten Indramayu (7-10 mdpl).

Metode yang digunakan adalah metode eksperimental dengan Rancangan Acak Kelompok (RAK) yang terdiri atas sembilan kombinasi perlakuan antara jumlah (dosis) yang dilepaskan dan interval aplikasi. Masing-masing perlakuan diulang tiga kali. Berikut adalah perlakuan yang diuji :

$\mathrm{p} 1 \mathrm{~m} 1=$ pelepasan 2 ekor pupa Eretmocerus sp./tanaman dengan interval 1 minggu

$\mathrm{p} 2 \mathrm{~m} 1=$ pelepasan 4 ekor pupa Eretmocerus sp./tanaman dengan interval 1 minggu

p3m1 = pelepasan 8 ekor pupa Eretmocerus sp./tanaman dengan interval 1 minggu

$\mathrm{p} 1 \mathrm{~m} 2=$ pelepasan 2 ekor pupa Eretmocerus sp./tanaman dengan interval 2 minggu

p2m2= pelepasan 4 ekor pupa Eretmocerus sp./tanaman dengan interval 2 minggu

$\mathrm{p} 3 \mathrm{~m} 2=$ pelepasan 8 ekor pupa Eretmocerus sp./tanaman dengan interval 2 minggu

p1m3= pelepasan 2 ekor pupa Eretmocerus sp./tanaman dengan interval 3 minggu

p2m3= pelepasan 4 ekor pupa Eretmocerus sp./tanaman dengan interval 3 minggu

$\mathrm{p} 3 \mathrm{~m} 3=$ pelepasan 8 ekor pupa Eretmocerus sp./tanaman dengan interval 3 minggu

Data yang diperoleh di analisis statistik dengan ANOVA menggunakan program SPSS Version 15. Apabila terdapat perbedaan diantara perlakuan, data selanjutnya dianalisis dengan Uji Jarak Berganda Duncan pada taraf 5\%.

Polibag ukuran $2 \mathrm{~kg}$ yang sebelumnya telah diisi tanah dan pupuk kandang $(1: 1)$ ditanami benih labu. Apabila tanaman labu telah cukup untuk digunakan sebagai media hidup B. tabaci (dua minggu setelah tanam), maka media dipindah ke dalam ruang perbanyakan yang sebelumnya telah disiapkan di rumah kaca. Sementara itu, tanaman kastuba didapat dari nursery yang kemudian dipindahkan ke rumah kaca.

Eretmocerus sp. disimpan dalam kurungan kasa kecil yang berisi tanaman labu dan kastuba yang telah diinfestasi $B$. tabaci. Ketersediaan inang berupa nimfa $B$. tabaci harus terus diperhatikan untuk mempertahankan perkembangbiakan Eretmocerus sp. Pupa Eretmocerus sp. dipanen lalu diletakkan di dalam toples kecil untuk mendapatkan imago parasitoid yang seragam (berumur satu hari) untuk digunakan saat perlakuan.

B. tabaci yang didapat dari lapangan, disimpan dalam kurungan kasa besar dan kecil yang berisi tanaman labu sebagai tanaman inang untuk $B$. tabaci. Setelah kepadatan nimfa mencukupi, tanaman labu tersebut dapat digunakan untuk perlakuan. Selanjutnya, dilakukan perawatan dan penggantian tanaman jika layu atau mati. Penambahan pupuk kimiawi berupa NPK dilakukan tiga minggu setelah tanam.

Disiapkan 30 polybag ukuran dua kilogram (kg) yang sebelumnya telah diisi dengan arang sekam bakar lalu ditanami bibit tomat. Nutrisi yang digunakan selama penanaman adalah larutan campuran NPK dengan perbandingan N 140-300 ppm; P 31-80 ppm dan K 160-300 ppm. Tempat penanaman di dalam rumah kasa dengan ukuran 6 $\mathrm{m} \times 5 \mathrm{~m} \times 2 \mathrm{~m}$.

Kertas pias dibuat dari kertas manila tebal berbentuk persegi dengan ukuran $5 \mathrm{~cm} \times 7,5 \mathrm{~cm}$. Pada bagian atas dan bawah pias dibuat lubang yang berfungsi untuk tempat meletakan pupa parasitoid yang diberi selotip. Pupa parasitoid dipindahkan satu-persatu dengan menggunakan spatula sesuai dengan dosis perlakuan.

Rumah kasa yang telah ditanami dengan tomat hidroponik, diinfestasikan dengan imago $B$. tabaci yang telah diperbanyak secara massal di rumah kaca. Setelah kepadatan nimfa cukup tinggi yaitu 300-1000 nimfa per tanaman (Zeng et al., 2004), yang didapat ketika usia tanaman tomat mencapai 5-6 minggu setelah tanam, kemudian masing-masing tanaman tomat disekat dengan kasa supaya perlakuan satu tidak mempengaruhi perlakuan lainya. Berikutnya, diinvestasikan pupa parasitoid sesuai dengan perlakuan.

Tingkat parasitasi ditentukan dengan mengamati jumlah nimfa yang terparasit.

$$
\mathrm{P}=\stackrel{\mathrm{N} 2}{------} \text { N1 } \quad \text { X 100\% }
$$

Keterangan:

$\mathrm{P}=$ Tingkat parasitasi (\%)

N2 = Jumlah nimfa B. tabaci yang terserang parasitoid

N1 = Jumlah nimfa B. tabaci yang diamati

\section{HASIL DAN PEMBAHASAN}

\section{Tingkat Parasitisasi Eretmocerus sp. terhadap $B$. tabaci}

Hasil percobaan ini menunjukkan bahwa pelepasan Eretmocerus sp. sebanyak 2 pupa, 4 pupa, dan 8 pupa per tanaman dengan interval aplikasi 1 minggu, 2 minggu dan 3 minggu sekali tidak berpengaruh terhadap tingkat parasitisasi 
Eretmocerus sp. sampai dengan minggu ke empat setelah pelepasan pertama. Perlakuan pelepasan Eretmocerus sp. dan interval aplikasinya baru terlihat pengaruhnya pada minggu kelima dan keenam setelah pelepasan pertama (Tabel 1).

Tabel 1. Tingkat parasitisasi Eretmocerus sp. terhadap B. tabaci pada tomat hidroponik.

\begin{tabular}{|c|c|c|c|c|c|c|}
\hline \multirow[b]{2}{*}{ Perlakuan } & \multicolumn{6}{|c|}{$\%$ Parasitisasi setalah pelepasan } \\
\hline & $\begin{array}{c}\text { Minggu } \\
\text { ke-1 }\end{array}$ & $\begin{array}{l}\text { Minggu } \\
\text { ke-2 }\end{array}$ & $\begin{array}{c}\text { Minggu } \\
\text { ke-3 }\end{array}$ & $\begin{array}{l}\text { Minggu } \\
\text { ke-4 }\end{array}$ & $\begin{array}{c}\text { Minggu } \\
\text { ke-5 }\end{array}$ & $\begin{array}{c}\text { Minggu } \\
\text { ke-6 }\end{array}$ \\
\hline p1m1= 2 pupa /1 minggu & $2,49 a$ & $2,43 a$ & $2,43 a$ & $4,02 \mathrm{a}$ & $9,25 \mathrm{a}$ & $16,13 a$ \\
\hline p1m2= 2 pupa/ 2 minggu & $5,23 \mathrm{a}$ & $6,51 \mathrm{a}$ & $6,51 \mathrm{a}$ & $10,82 \mathrm{a}$ & $12,11 \mathrm{a}$ & $13,90 \mathrm{a}$ \\
\hline p1m3= 2 pupa/ 3 minggu & $3,67 a$ & $5,25 a$ & $5,25 a$ & $5,34 \mathrm{a}$ & $10,09 a$ & $11,57 \mathrm{a}$ \\
\hline p2m1 = 4 pupa/ 1 minggu & $4,28 \mathrm{a}$ & $5,61 \mathrm{a}$ & $5,61 \mathrm{a}$ & $6,20 \mathrm{a}$ & $16,30 \mathrm{ab}$ & $17,11 \mathrm{a}$ \\
\hline $\mathrm{p} 2 \mathrm{~m} 2=4 \mathrm{pupa} / 2 \mathrm{minggu}$ & $5,29 a$ & $8,64 a$ & $8,64 \mathrm{a}$ & $11,42 \mathrm{a}$ & $12,97 \mathrm{a}$ & $17,25 a$ \\
\hline p2m3= 4 pupa/ 3 minggu & $3,87 a$ & $4,16 a$ & $4,16 a$ & $6,23 a$ & $8,72 a$ & $12,44 \mathrm{a}$ \\
\hline $\mathrm{p} 3 \mathrm{~m} 1=8 \mathrm{pupa} / 1 \mathrm{minggu}$ & $3,92 a$ & $8,05 a$ & $8,05 a$ & $7,24 \mathrm{a}$ & $22,55 b$ & $24,63 b$ \\
\hline $\mathrm{p} 3 \mathrm{~m} 2=8 \mathrm{pupa} / 2$ minggu & $4,43 a$ & $6,62 a$ & $6,62 a$ & $5,65 a$ & $9,31 \mathrm{a}$ & $11,67 \mathrm{a}$ \\
\hline $\mathrm{p} 3 \mathrm{~m} 3=8 \mathrm{pupa} / 3$ minggu & $3,43 a$ & $3,73 a$ & $3,73 a$ & $4,64 \mathrm{a}$ & $10,03 a$ & $10,69 \mathrm{a}$ \\
\hline
\end{tabular}

Keterangan: Angka rata-rata perlakuan yang diikuti oleh huruf yang sama pada kolom yang sama tidak berbeda nyata menurut Uji Jarak Berganda Duncan pada taraf nyata 5\%.

Pada Tabel 1 tampak bahwa tingkat parasitisasi pada semua kombinasi perlakuan masih sangat rendah sampai minggu ke empat setelah pelepasan pertama dengan tingkat parasitisasi berkisar antara 4,02\%-11,42\%. Tingkat parasitisasi mulai terlihat nyata pada minggu kelima dengan tingkat parasitisasi tertinggi pada perlakuan pelepasan 4 pupa dan 8 ekor pupa parasitoid pertanaman masing-masing dengan interval 1 minggu. Tingkat parasitisasi tertinggi pada kedua perlakuan tersebut masing-masing mencapai $16,30 \%$ dan 22,51\%.

Pada pengamatan minggu keenam tingkat parasitisasi parasitoid Eretmocerus sp. mulai menunjukkan kenaikan yang cukup signifikan. Berturut-turut adalah perlakuan p2m2 (pelepasan 4 pupa dengan interval 2 minggu sekali), dan p2m1(pelepasan 4 pupa dengan interval 1 minggu sekali) yang tingkat parasitisasinya masing-masing mencapai $17,25 \%$ dan $17,11 \%$ dan berbeda nyata dengan perlakuan yang lainnya. Hal ini dimungkinkan karena jumlah Eretmocerus sp. yang berada pada tanaman inang populasinya semakin bertambah. Tambahan populasi Eretmocerus sp. ini berasal dari pelepasan perlakuan pada minggu sebelumnya dan dari imago baru yang muncul dari nimfa B. tabaci terparasit.

Tingkat parasitisasi tertinggi pada perlakuan dengan dosis 8 pupa Eretmocerus sp. dan interval 1 minggu sekali (p3m1) dengan persentase 24,63\%. Diduga jumlah populasi Eretmocerus sp. pada perlakuan ini paling banyak karena pada perlakuan p3m1 ini dilepaskan 8 pupa Eretmocerus sp. setiap minggunya dalam waktu enam minggu. Selain itu, populasi Eretmocerus sp. mendapatkan tambahan imago baru yang muncul dari nimfa $B$. tabaci terparasit. Lambatnya perkembangan Eretmocerus sp. ini diduga karena parasitoid memerlukan waktu untuk beradaptasi. Berbedanya tanaman inang diduga mengakibatkan Eretmocerus sp. harus beradaptasi kembali dengan tanaman inang yang baru sehingga tingkat parasitisasi diawal aplikasi menjadi rendah. Menurut Purnomo, (2007) musuh alami khususnya parasitoid sering menggunakan senyawa kimia yang berasal dari tanaman inang yang menstimulasi pencarian inang dan peletakan telur. Lama perkembangan dari telur hingga munculnya imago Eretmocerus sp. pada suhu $29^{\circ} \mathrm{C}$ adalah 16 hari (Powel \& Bellow, 1992 dalam Ardeh, 2004).

Rendahnya tingkat parasitisasi Eretmocerus sp. terhadap $B$. tabaci pada tanaman tomat hidroponik dalam percobaan ini diduga karena beberapa faktor yaitu tingginya populasi $B$. tabaci pada aplikasi minggu pertama, temperatur dan kelembaban di rumah kaca, morfologi tanaman inang, jumlah pupa (dosis) Eretmocerus sp. yang dilepaskan, perbedaan jenis tanaman inang ketika perbanyakan dan percobaan, dan serangan penyakit embun tepung (Oidium sp.). 
Tingginya Populasi B. tabaci pada Aplikasi Minggu Pertama

Sebelum dilakukan pelepasan pertama, dilakukan perhitungan kapadatan B. tabaci dalam satu tanaman yaitu berkisar antara 300 nimfa sampai 1000 nimfa, sedangkan populasi B. tabaci dikatakan tinggi jika mencapai 1000 nimfa dalam satu greenhouse (Zheng et al., 2005). Menurut Kfir (1983) dalam Djuwarso dkk. (1997) pengaruh kepadatan inang yang terlalu tinggi dapat menyebabkan turunnya efisiensi daya mencari inang, menurunnya tingkat kesuburan, menurunnya populasi betina yang ditemukan dan meningkatnya proporsi serangga yang kerdil. Banyaknya inang yang tersedia menyebabkan semakin lamanya parasitoid melakukan pemilihan inang, sehingga memungkinkan pada kepadatan nimfa yang tinggi, daya cari inang dari parasitoid semakin lambat.

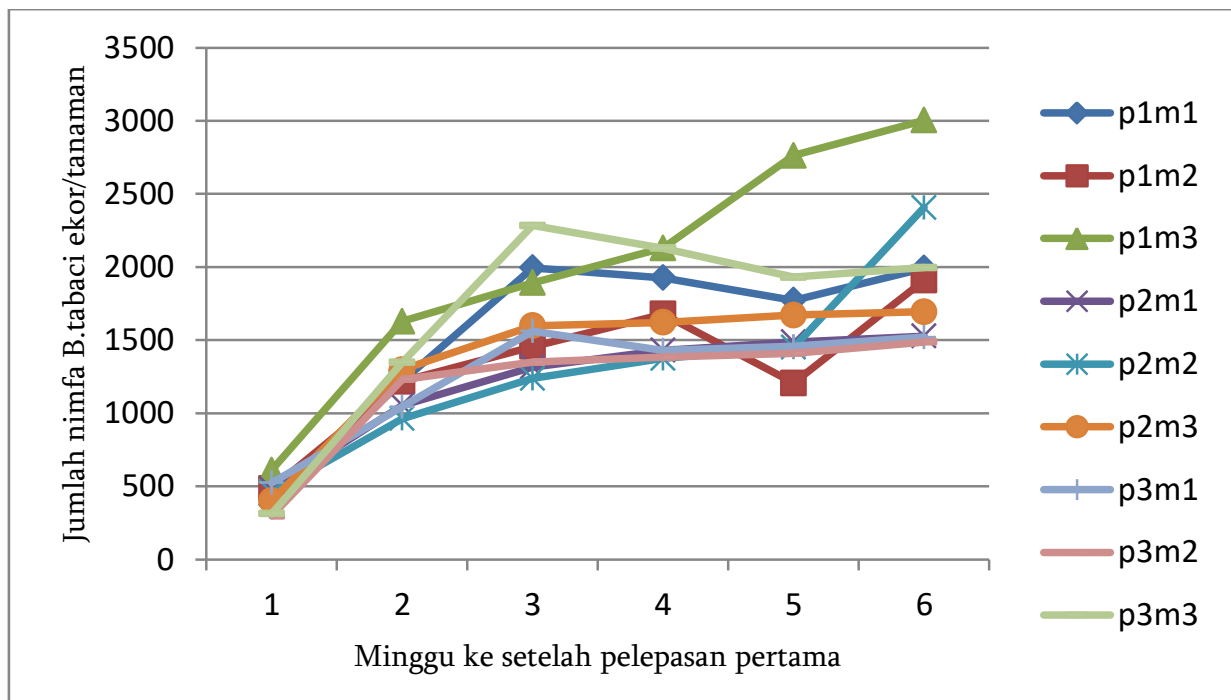

Gambar 1. Kepadatan nimfa B. tabaci pada tanaman tomat hidroponik. Keterangan: Perhitungan dengan metode sampling, satu sampel terdiri dari 4 tangkai daun majemuk/tanaman.

Temperatur dan Kelembaban Rumah Kaca

Temperatur dan kelembaban dapat memengaruhi tingkat parasitisasi parasitoid (Qiu et al., 2004). Pada penelitian yang telah dilakukan ini didapatkan suhu dan kelembaban rata-rata selama 43 hari adalah $24,6{ }^{\circ} \mathrm{C}-33,87{ }^{\circ} \mathrm{C}$ dan $52,88 \%-78,93 \%$ pada siang hari serta $18,88^{\circ} \mathrm{C}-22,56^{\circ} \mathrm{C}$ dan $71,51 \%$ 92,95\% pada malam hari. Meskipun suhu dan kelembaban rata-rata termasuk normal, tetapi pada beberapa waktu tertentu suhu tertinggi di siang hari mencapai $37^{\circ} \mathrm{C}$ dan suhu terendah pada malam hari mencapai $16,7^{\circ} \mathrm{C}$, serta $47 \%$ tingkat kelembaban terendah di siang hari dan $97 \%$ pada malam hari. Tingginya suhu pada siang hari diduga karena bentuk dan tinggi rumah kaca yang tidak sesuai standar. Atap rumah kaca terbuat dari plastik transparan 0,8 inch dengan tinggi 2 meter. Hal ini menyebabkan panas matahari terlalu banyak yang diserap dan panas tertahan di dalam rumah kaca tanpa aliran udara yang seimbang sehingga suhu di rumah kaca akan tinggi. Selain itu, sekat dari kain yang digunakan untuk penghalang antar perlakuan menjadikan aliran udara dari luar sulit untuk masuk.

\section{Morfologi Tanaman Inang}

Jenis tanaman inang, bentuk dan panjang trichoma, lebar daun tanaman inang turut memengaruhi tingkat parasitisasi Eretmocerus sp. (Ardeh, 2004; Suarez et al., 2003). Dari beberapa tanaman budidaya yang menjadi inang $B$. tabaci telah berhasil diketahui tingkat parasitisasi parasitoid Eretmocerus sp. yaitu pada tanaman Gossypium hirsutum (kapas) di Afrika Barat mencapai $88,7 \%$ dan pada tanaman Convolvulus arvensis (bunga sepatu) 38-69\% (Naveed et al., 2003; Otoidobiga, 2003). Rendahnya tingkat parasitisasi Eretmocerus sp. pada tanaman tomat hidroponik diduga karena bentuk morfologi dari tanaman tomat khususnya daun. Bentuk daun tomat yang oval dengan tepian menyirip, berambut (memiliki trikoma), dan panjang daun antara $10 \mathrm{~cm}-35 \mathrm{~cm}$ membuat Eretmocerus sp. terhambat dalam proses pencarian inang. Eretmocerus sp. lebih menyukai daun yang lebar dari pada daun yang sempit. Hal inilah yang menyebabkan tingkat parasitisasi Eretmocerus sp. pada tanaman labu dan Pointsettia lebih tinggi daripada pada gulma Ageratum 
conizoides (Gerling, 1990). Selain itu, tanaman tomat memiliki cabang (daun majemuk) yang banyak (Puspita, 2008) mencapai 27-30 cabang daun majemuk. Hal ini diduga mengakibatkan Eretmocerus sp. tidak melakukan pencarian inang dengan maksimal. Eretmocerus sp akan menghabiskan waktu untuk pencarian inang dan hanya punya sedikit waktu untuk oviposisi.

Jumlah Pupa (Dosis) Eretmocerus sp yang Dilepaskan Pada minggu ke-6 didapatkan tingkat parasitisasi yang tinggi (berbeda nyata dengan perlakuan lainnya) yaitu 24.63\%. Namun tingkat parsitisasi yang didapatkan masih rendah. Selain beberapa faktor yang telah dijelaskan sebelumnya diduga jumlah Eretmocerus sp. yang dilepaskan yaitu 2 pupa, 4 pupa, dan 8 pupa terlalu sedikit dan tidak seimbang dengan jumlah populasi $B$. tabaci. Pelepasan Eretmocerus sp. dengan dosis 4-8 imago/tanaman (Van Driesche \& Lyon, 2003) dan dosis 2-8 imago/m² (Biobest, 2008 ; Syngenta Bioline, 2008) lebih tepat dilakukan untuk pengendalian $B$. tabaci pada saat populasi rendah atau lebih cenderung sebagai tindakan pengendalian preventif untuk mencegah meningkatnya populasi $B$. tabaci. Sementara itu, untuk tindak pengendalian pada populasi B. tabaci yang tinggi (pengendalian kuratif), Zheng et al. (2005) mengatakan bahwa dalam pelepasan parasitoid, jumlah Eretmocerus sp. sebaiknya 3:1 terhadap $B$. tabaci. Hasil penelitian di rumah kaca di China menunjukkan bahwa melepaskan 3000 imago Eretmocerus sp. dalam 1 greenhouse mampu menekan populasi $B$. tabaci lebih dari 50\%.

\section{Perbedaan Jenis Tanaman Inang Ketika Perbanyakan dan Percobaan}

Perbedaan antara tanaman inang untuk perbanyakan dan tanaman inang untuk percobaan diduga menyebabkan Eretmocerus sp. memerlukan waktu kembali untuk beradaptasi sehingga pada hasil pengamatan pada minggu ke-1 sampai minggu ke-4 tingkat parasitisasi masih sangat rendah. Pada pengamatan minggu selanjutnya tingkat parasitisasi meningkat karena diduga Eretmocerus sp. telah beradaptasi di rumah kaca dan mendapatkan tambahan imago baru dari perlakuan selanjutnya dan dari kemunculan imago Eretmocerus sp. dari nimfa B. tabaci terparasit dari perlakuan sebelumnya. Lama perkembangan dari telur hingga munculnya imago Eretmocerus sp. pada suhu $29^{\circ} \mathrm{C}$ adalah 16 hari (Powel \& Bellow, 1992 dalam Ardeh, 2004).

\section{Serangan Penyakit Embun Tepung (Oidium sp.)}

Selama percobaan dilakukan, seluruh tanaman tomat hidroponik terserang oleh penyakit embun tepung yang disebabkan oleh pathogen jamur Oidium sp. Gejala khas dari serangan Oidium sp. adalah permukaan bagian atas daun tomat diselimuti oleh bercak-bercak putih seperti tepung. Pada kondisi yang sesuai, bercak putih tersebut berkembang dengan cepat sehingga menutupi seluruh organ tanaman yang diserang setelah itu daun akan menguning, mengkeriting dan mati (Semangun, 2004). Sama halnya dengan nimfa $B$. tabaci, serangan penyakit embun tepung dimulai dari daun tua yang berada di bagian bawah sehingga diduga terjadi kompetisi dalam hal penyerapan nutrisi oleh Oidium sp. pada permukaan atas daun dan nimfa $B$. tabaci di bagian bawah permukaan daun. Menurut Mau \& Kessing (2007), nimfa $B$. tabaci dari crawlers (nimfa instar satu) menetap untuk menghisap cairan makanan sampai menjadi nimfa instar empat. Terjadinya kompetisi ini menyebabkan daun tomat lebih cepat mengering dan mati. Hal terebut berpengaruh terhadap tingkat parasitisasi karena bentuk dan ukuran nimfa $B$. tabaci menjadi tidak optimal. Hal ini mengurangi tingkat preferensi atau pemilihan inang oleh Eretmocerus sp. Selama percobaan ini diketahui bahwa Eretmocerus sp. memparasiti nimfa B. tabaci bermula dari daun tua pada bagian bawah tanaman tomat dan lebih memilih memarasiti nimfa $B$. tabaci pada instar 1, instar 2 dan instar 3 (Greenberg et al., 2008).

\section{SIMPULAN}

Kombinasi perlakuan antara dosis (jumlah pupa) yang dilepaskan dan interval pelepasan memengaruhi tingkat parasitisasi Eretmocerus sp. pada tomat hidroponik pada minggu kelima dan keenam setelah pelepasan pertama. Tingkat parasitisasi tertinggi terjadi pada pelepasan 8 pupa dengan interval 1 minggu (p3m1) pada minggu keenam dengan tingkat parasitisasi 24,63\%. Akan tetapi, tingkat parasitisasi pada minggu pertama sampai minggu keempat sangat rendah berkisar antara 2,49\%-11,42\% atau seluruh perlakuan tidak berbeda nyata. Rendahnya tingkat parasitisasi Eretmocerus sp. pada penelitian ini disebabkan oleh tingginya populasi B. tabaci pada perlakuan pertama, 
tingginya temperatur di dalam rumah kaca, perbedaan tanaman inang ketika perbanyakan dan percobaan, kurangnya jumlah Eretmocerus sp. yang dilepaskan, dan serangan jamur Oidium sp. penyebab penyakit embun tepung.

\section{UCAPAN TERIMAKASIH}

Penulis mengucapkan penghargaan dan terimakasih kepada Sdr. Ema Budiman yang telah membantu dalam pelaksanaan penelitian dan Departemen Hama dan Penyakit Tumbuhan yang telah membantu dalam membiayai sebagian dari penelitian ini.

\section{DAFTAR PUSTAKA}

Ardeh, MJ. 2004. Whitefly control potential of Eretmocerus parasitoids with different reproductive modes. [Thesis]. Wagenigen Universiteit. Germany.

Bonaro, O, A Lurette, C Vidal, and J Fargues. 2007. Modelling temperature-dependent bionomics of Bemisia tabaci (Q-biotype). Physiological Entomology. 32:50-55.

Djuwarso, T, W Tengkano, D Koswanudin, dan D Damayanti. $\quad 1997 . \quad$ Potensi Trichogrammatoidea bactrae bactrae, Parasitoid telur Penggerek Polong Kedelai. Prosiding Seminar PEI.

Gerling, D. 1990. Natural enemies of whiteflies: Predators and parasitoids in Whiteflies: their Bionomics, Pest Status and Management (D Gerling, Ed.). Intercept, United Kingdom. Pp. 147-185.

Gerling, D, and RT Mayer (Eds.). 1996. Bemisia 1995: Taxonomy, Biology, Damage, Control and Management. Intercept, United Kingdom.

Gerling, D, O Alomar, and J Arno. 2001. Biological control of Bemisia tabaci using predators and parasitoids. Crop Prot. 20:779-799.

Greenberg, SM, WA Jones, and TX Liu. 2008. Bemisia tabaci (Homoptera: Aleyrodidae) instar effects on rate of parasitism by Eretmocerus mundus and Encarsia pergandiella (Hymenoptera: Aphelinidae). Entomol. Sci. 11:97-103.

Mau, RLF, and JLM Kessing. 2007. Bemisia tabaci (Gennadius). Department of Entomology Honolulu, Hawai. Available online at: http://www.extento.hawaii.edu/kbase/crop/
Type/b_tabaci.htm. (accessed 15 January 2017).

Naveed, M, A Rafique, and T Zahida. 2003. Status of Bemisia tabaci on cotton and population dynamics of parasitoids on alternate host plant in Pakistan. Bilogical Control Sessoin IV. The $3^{\text {rd }}$ International Bemisia Workshop Barcelona 17-20 March 2003.

Oka, IN. 2005. Pengendalian Hama Terpadu dan Implementasinya di Indonesia. Gadjah Mada University Press, Yogyakarta.

Otoidobiga, LC. 2003. Susceptibility of field populations of adult Bemisia tabaci Gennadius (Homoptera: Aleyrodidae) and Eretmocerus sp. (Hymenoptera: Aphelinidae) to cotton insecticides in Burkina Faso (West Afrika). Pest Manag Sci. 59(1): 97-106.

Purnomo, H. 2007. Augmentasi (Inokulasi \& Inundasi). Tersedia online pada: http://elearning.unej.ac.id/courses/PNH165 3/document/Pengantar_Pengendalian_Haya ti.pdf?cidReq=PNH1653. (diakses 7 Januari 2017).

Qiu, YT, JC van Lenteren, YC Drost, and CJAM Posthuma-Doodeman. 2004. Life History parameters of Encarsia formosa, Eretmocerus eremicus and E. mundus, aphelinid parasiotidds of Bemisia argentifolii (Homoptera: Eleyrodidae). Euro.J. Entomol. 101:83-94.

Selina, P, and ME Bledsoe. 2002. Hothouse Hydroponic Tomato Timeline. Available online at: http://www.fargro.co.uk/biologicals/pfib2.jpg\&imgrefurl. (accessed 15 Februari 2017).

Suarez, H, JR Esteves, and A Carneo. 2003. Population dynamics and natural enemies of Bemisia tabaci on different horticultural crops in the Canari Islands. Bilogical Control Sessoin IV. The $3^{\text {rd }}$ International Bemisia Workshop Barcelona 17-20 March 2003.

Untung, K. 2001. Pengantar Pengelolaan Hama Terpadu. Gajah Mada University Press, Yogyakarta.

Van Driesche, RG, and S Lyon. 2003. Commercial adoption biological control-based IPM for whiteflies in poinsettia. Florida Entomologist. 86(4):481-483. 
Wiyono, S. 2007. Perubahan iklim dan ledakan hama penyakit. Seminar Sehari tentang Keanekaragaman Hayati Di tengah Perubahan Iklim: Tantangan Masa Depan Indonesia. Tersedia online pada: http://www.rimbawan.com. (diakses 20 Januari 2017).

Zheng, L, Y Zhou, and K Song.2005. Augmentative biological control in greenhouses experiences from China.
Second International Symposium on Biological Control of Arthropods. September 12-16, 2005. Davos, Switzerland.

Zolnerowich, G, and M Rose. 2008. The Genus Eretmocerus in Classical Biological Control of Bemisia tabaci in the United States - A Review of Interagency Research and Implementation (J Gould, K Hoelmer, J Goolsby, Eds.). Progress in Biological Control, Vol 4. Springer, Dordrecht. 